\title{
Ungulate browsing causes species loss in deciduous forests independent of community dynamics and sil- vicultural management in Central and Southeastern Europe
}

\author{
E.D. Schulze, O. Bouriaud, J. Wäldchen, N. Eisenhauer, H. Walentowski, C. Seele, \\ E. Heinze, U. Pruschitzki, G. Dănilă, G. Marin, D. Hessenmöller, L. Bouriaud, \\ M. Teodosiu
}

Schulze E.D., Bouriaud O. , Wäldchen J., Eisenhauer N., Walentowski H., Seele C., Heinze E., Pruschitzki U., Dănilă G., Marin G., Hessenmöller D., Bouriaud L., Teodosiu M., 2014. Ungulate browsing causes species loss in deciduous forests independent of community dynamics and silvicultural management in Central and Southeastern Europe. Ann. For. Res. 57(2): 267-288, 2014.

Abstract. Grid-based inventories of 1,924 deciduous forests plots in Germany and 4,775 in Romania were used to investigate tree species composition as affected by browsing and grazing under different forest management (rotation forestry, selectively cut forest, protected forest). At regional scale, the loss of tree species in the dominant layer was between 52 to $67 \%$ in Germany and of 10 to $30 \%$ in Romania, with largest effects in protected nature reserves in Germany. At plot level, only 50\% (Germany) to 54\% (Romania) of canopy species were found in the regeneration layer with a height of $1.5 \mathrm{~m}$. Browsing was influenced by the proportion of Fagus in the regenerating trees in Germany, and by stand density, basal area, and management in both regions. Structural equation modeling explained 11 to $26 \%$ of the variance in species loss based on the fresh loss of the terminal bud in the winter prior to the inventory work (one season browsing). Browsing (and grazing in Romania) is shown to be a significant cause of species loss across both countries and all management types. Potential cascading effects on other organisms of deciduous forest ecosystems are discussed. We conclude that the present hunting practices that support overabundant ungulate populations constitute a major threat to the biodiversity of deciduous forests in Germany and Romania and to other places with similar ungulate management, and that changes my only be possible by modernizing the legal framework of hunting. Keywords selectively cut forest; age-class forest; protected unmanaged forest; roe deer; tree species diversity; forest regeneration, community dynamics, deciduous forest.

Authors. E.D. Schulze (dschulze@bgc-jena.mpg.de), J. Wäldchen, C. Seele, D. Hessenmöller - Max-Planck Institute for Biogeochemistry, PO Box 100164 07701 Jena, Germany, U. Pruschitzki - Max-Planck Institute for Biogeochemistry, PO Box 100164, 07701 Jena, Germany; German Centre for Integrative 
Biodiversity Research (iDiv) Halle-Jena-Leipzig, Deutscher Platz 5e, 04103 Leipzig, Germany; Institute for Biology, University of Leipzig, Johannisallee 21, 04103 Leipzig, Germany, O. Bouriaud, G. Marin, M. Teodosiu - Forest Research and Management Institute, Bucharest 128 Bd. Eroilor, Voluntari, Romania, N. Eisenhauer - Institute for Ecology, University of Jena, 07701 Jena, Germany; German Centre for Integrative Biodiversity Research (iDiv) HalleJena-Leipzig, Deutscher Platz 5e, 04103 Leipzig, Germany; Institute for Biology, University of Leipzig, Johannisallee 21, 04103 Leipzig, Germany, H. Walentowski - Bavarian State Inst. of Forestry, Hans-Carl-von-Carlowitz-Platz 1, 85354 Freising, Germany, E. Heinze - Förstereistrasse 34, 01099 Dresden, Germany, G. Dănilă, L. Bouriaud - University Ştefan del Mare of Suceava, 13 University Street, 720229 Suceava, Romania.

Manuscript received September 19, 2014; revised November 13, 2014; accepted November 20, 2014; online first November 27, 2014.

\section{Introduction}

Among disturbances, browsing by ungulates has direct effects on the establishment and maintenance of plant species and indirect effects on other organisms (Lessard et al. 2012). The consequences of this disturbance regime are closely related to forest ecosystem resilience and thus of particular importance for forest management. An "overpopulation" of deer would exist if certain management goals cannot anymore be reached. However there is no fixed deer-density ascribing "overpopulations", as the effects of browsing is depending on the grazing species and its preference for certain plant species, and on forest management goals (monoculture versus mixed forests). In contrast to agriculture, managing ungulate browsing is difficult because the effects of browsing are not immediately reversible in forests due to the long life-time of trees, even if ungulate populations were to decline (Tanentzap et al. 2011).

Quantifying a balanced ungulate density satisfying multiple objectives (e.g. stand characteristics and resilience, productivity, biodiversity, and economic output) is a major issue in managing forests. Browsing can strongly influence the structure, composition, growth and succession of forest stands as a result of the intensity and the selectivity of browsing damage (Klötzli 1965, Skarpe \& Hester 2008, 268
Gerhadt et al. 2013). Even Carlowitz (1713), who coined the concept of sustainable forestry, recommended already in the 18 th century that "browsed trees should be cut, because such damaged individuals subsequently exhibit reduced growth" (quote translated from German). Preferred (i.e. more palatable) species lose their competitiveness mainly from browsing of the terminal bud. Tree height in the regeneration layer of browsed species decreases as deer density increases (Horsley et al., 2003; Tremblay et al., 2007), and reduction of height has a major effect on competitive ability. Thus, deer may alter inter-specific competition such that avoided (i.e., less palatable) species benefit from browsing at the expense of preferred ones ("apparent competition", Holt 1977).

Harper (1977) described such situations where plant species that would dominate a plant community in the absence of herbivory, are disadvantaged by herbivory to an extent where less preferred or grazing-tolerant plant species attain dominance. Crawley (1988) generalized these observations such that a frequency-dependent herbivore feeding can be a force to increasing plant-species richness, allowing the recruitment of grazing-tolerant species. If this type of interaction would operate for forest tree species, we would expect higher tree diversity in the regeneration of stands, which are grazed by ungulates than in the canopy if management is excluded (protected sites). 
In managed stands one tendency would be to reduce the action of deer, while supporting subdominant tree species of commercial value by tending and thinning. Thus management would tend to maintaining diversity in deciduous forests. However, forest managers are not independent in their decisions, as deer management depends on hunters, who lease properties across boarders to reach the legally required minimum hunting area. Present strategies (mainly hunting for trophies; Crişan 1994, Gautschi 2010), and the improved food supply with high yielding crops in agriculture and with feeding of deer in forests in winter caused an increasing deer population globally (Milner et al. 2007), which would impact not only tree diversity, but result also in cascading impacts on other animal taxa (Lessard et al. 2012, Côté et al. 2004).

In this study the effects of ungulates on tree species diversity were investigated by quantifying changes in tree species composition between the canopy and different regeneration layers of different forest types in Romania and Germany. The focus is on browsing of deciduous trees by roe deer, because of its known effect on tree regeneration (see e.g. Klötzli 1965). We neglect bark peeling and fraying by red deer, which requires a separate analysis. Forest management options range in the investigated areas from age-class rotation forest to totally protected forest reserves. The overall hypothesis is that the effects of ungulate browsing lead to a species loss in temperate deciduous forest rather than to an enrichment of tree diversity, and that the level of loss depends on the type of forest management. Different management systems (age class forests with and without thinning, selective logging, Schulze et al. 2014) may tolerate different levels of browsing/grazing and still reach the management goals. Based on our observations we discuss the legal implications of hunting and the cascading effects of tree species loss for ecosystem diversity.

\section{Methods}

\section{Study regions and grid-based inventories}

The investigation was conducted between 2008 and 2012 in Southeastern Europe (Romania) and in Central Europe (Germany), exhibiting different levels of browsing intensities. Gridbased inventories were used to sample a large range of forest habitats, ages, structures, management types, and browsing conditions.

In Romania, the investigation is based on the Romanian National Forest inventory (NFI), which includes forests, woodlands, and trees outside forests. The NFI covers the entire country of Romania (approx. 500 x $500 \mathrm{~km}$ area) on a $4 \times 4 \mathrm{~km}$ grid in hills and mountains and a $2 \times 2 \mathrm{~km}$ grid in lowlands (Marin et al. 2009). The measurements were taken on clusters of four plots located in the corners of a 250 x $250 \mathrm{~m}$ square. For the present study, plots at low altitude (250 to $650 \mathrm{~m}$ above sea level) with deciduous forest cover were selected, which are in total 4,775 plots of 2,194 clusters from the $4 \times 4 \mathrm{~km}$ grid and 55 from the $2 \times 2$ $\mathrm{km}$ grid. The mean annual daily temperature ranges from 6 to $8^{\circ} \mathrm{C}$ and precipitation ranges from 600 to $800 \mathrm{~mm}$.

In Germany, the investigation was focused on the Hainich-Dün region, in the Northwestern part of Thuringia. The region of approx. $200 \times 50 \mathrm{~km}$ contains different land use types (agriculture, forest, infrastructure). A $100 \mathrm{x}$ $100 \mathrm{~m}$ grid was placed in the core of the forest areas, excluding forest margins (Hessenmöller et al. 2011), which resulted in a total of 1,924 plots. Elevation ranges from 300 to $600 \mathrm{~m}$ above sea level. The mean annual daily temperature ranges from 6 to $8^{\circ} \mathrm{C}$ and precipitation ranges from 600 to $750 \mathrm{~mm}$.

We are aware that comparisons between regions that are more than $1,000 \mathrm{~km}$ apart contain inherent weaknesses with respect to geological substrates and management histories. Nevertheless, the climate conditions are very similar in both regions and the species composition is 
very close (Schulze et al. 2014). Both regions were covered by forest after the Pleistocene from the same tree refugia (Lang 1994). Thus, a comparison of both regions with respect to browsing and management of the regeneration appears legitimate, and it would strengthen the conclusions if similar patterns emerge.

\section{Inventory measurements}

Forest management was recorded for each inventory plot as (i) age-class (rotation) forest consisting of even-aged stands established after harvest, (ii) selectively cut forest consisting of uneven-aged stands with single tree harvest at target diameter, and (iii) protected unmanaged forest reserves.

Canopy measurements followed the identical protocols in the both regions. Circular plots covered $500 \mathrm{~m}^{2}$ (radius $12.62 \mathrm{~m}$ ) in young stands and $1000 \mathrm{~m}^{2}$ area (radius $17.8 \mathrm{~m}$ ) in old-growth stands. All living and dead trees $>5.6 \mathrm{~cm}$ diameter at breast height $(\mathrm{DBH})$ were recorded depending on tree size in concentric sub-circles: trees with $5.6 \leq \mathrm{DBH} \leq 28.5 \mathrm{~cm}$ were measured within a $200 \mathrm{~m}^{2}$ inner circle and trees with $\mathrm{DBH} \geq 28.5 \mathrm{~cm}$ within a concentric $500 \mathrm{~m}^{2}$ circle (Hessenmöller et al. 2011). Plots with exotic, introduced species (e.g., Pseudotsuga menziesii) were discarded.

For some tree genera (Quercus: two species, Tilia: two species, Sorbus: three species, Ulmus: three species) determination to species level was not possible in winter. Therefore, the analysis of diversity in Germany is based on genera for these groups. Using genera for some species in Germany and actual species in Romania affects about $10 \%$ of the plots, and it is unlikely to change the results. Tree species diversity increased with the number of investigated plots, saturating at about 21 species in Romania and at 16 taxonomic units in Germany with 500 and 1,000 plots, respectively (species accumulation curves: Supplement-Fig. S1). Stand parameters are summarized for both regions in the supplement (Supplement-Table
S1).

Regeneration was sampled on rectangular plots of $8 \mathrm{~m}^{2}$ in Germany. In Romania, regeneration was sampled on two satellite plots located at $10 \mathrm{~m}$ from one another. Each satellite plot is constituted of two concentric circular plots of $1 \mathrm{~m}$ radius for saplings between 10 $\mathrm{cm}$ and $50 \mathrm{~cm}$ height, and $1.78 \mathrm{~m}$ radius for saplings beyond $50 \mathrm{~cm}$ height. Observations in fenced areas show that these plot sizes are large enough to support the maximum diversity of tree saplings for the investigated height classes (Schulze 2014). The regeneration layer (see also Supplement-Table S1) was divided into low, intermediate and tall regeneration as: 0.2 to $0.5 \mathrm{~m}$ being Height Class 1 ( $\mathrm{HC} 1)$; 0.5 to $1.3 \mathrm{~m}$ in Romania and 0.5 to $1.5 \mathrm{~m}$ in Germany being Height Class 2 (HC2); and 1.3 $\mathrm{m}$ in Romania and $1.5 \mathrm{~m}$ in Germany to $3 \mathrm{~m}$ being Height Class 3 (HC3). For each height class, the number and species identity of all individuals were recorded. The transition from $\mathrm{HC} 1$ to $\mathrm{HC} 3$ takes about 10 to 20 years under unfenced conditions in Germany.

Ungulate browsing was recorded as loss of the terminal bud during the current growing season. When interpreting browsing damage, one must consider that this damage happens each year. We did not record browsing on lateral branches, because height growth is the main factor for success in dense regeneration (Burschel \& Huss 2002). Old and repeated browsing damage of terminal shoots were also not accounted for. Thus, total impact was underestimated. Repeatedly browsed individuals become distorted and die from competition with un-browsed neighbors.

Browsing was at different levels in Romania and Germany $(p<0.001)$, despite a great similarity in canopy tree species composition and total canopy species number. Thus, the comparison of these two countries may detect the specific effects of browsing. However, there are differences. Despite of lower deer populations in Romania, another type of disturbance emerged during the evaluation of the data. In 
addition to deer and predators, we must consider domesticated animals in Romania, where the total number of sheep (12.5 million) plus goats (1.6 million) is equivalent to about 2.1 head per ha forest as a national average. The population of goats has increased significantly since 2002: from 0.7 million in 2003 (National Institute of Statistics 2003) to 1.7 million in 2012 (MADR 2012). This increase occurred mainly on small and medium sized farms (with 20 to 500 goats per farm) grazing both agricultural land and forest, mostly in the lowlands of southern and eastern Romania. We do not have a precise estimate of the amount of grazing in forests and on our inventory plots because forest grazing is illegal. But there is sufficient evidence and field observations by the authors to confirm its large-scale existence and impact. Grazing pressure is also acknowledged in the Romsilva reports (Ministerul Mediului şi Pădurilor 2011) and the media report grazing even in nature reserves (e.g. Gardianul, 27.7.2007). Sheep and goats affect mainly the lower-most height class (HC1).

\section{Estimates of the mean age of trees in a plot}

Stand age is an important variable in forest succession and it is strongly related to species richness (Ellenberg 1978). To estimate stand age in uneven-aged stands is difficult. Here we used a general relationship between DBH and the measured tree ages at DBH in Romania and at stump height in Thuringia (SupplementFig. S2). For Romania, a total of 546 trees and for Germany a total of 114 trees of Fagus, Quercus and Acer originating from all types of forest management were used for the reduced major axis regression model (RMA, Sokal and Rohlf 1995). The slope of the regression line was significantly higher in Romania than in Germany $(p<0.05)$, partly because cores were taken at DBH in Romania and at tree base in Germany. Stand age was estimated by averaging the DBH-related age of all trees per plot. Thus, stand and plot age are represented by the mean age of trees in a plot. There was no significant effect of species identity on this relation.

\section{Estimate of near-ground light conditions}

The large number of inventory points represented a broad range of light conditions. Even though the light conditions at the regeneration height were estimated by eye, as canopy closure, in the statistical analysis (see chapter 2.6), the basal area was taken as a continuous variable surrogating for light conditions on the ground. Basal area and light-level estimates were closely correlated (ANOVA with the categorical independent variable "light level" and the continuous variable "basal area", $p<0.01$ for Romania and Germany).

\section{Regional estimates of deer populations}

In Romania, the density of roe deer (Capreolus capreolus L.) and red deer (Cervus elaphus L.) was estimated for 347 hunting districts each covering 2,500 to 23,000 ha, matching the forest inventory (Table 1). These governmental data have never been aggregated and published before, and the survey has not been repeated. Animal numbers are based on independent counts of tracks in fresh snow in March 2002, on a national basis. These counts are compared with the reports of the rangers. The large predators (wolf: Canis lupus L., bear: Ursus arctos L., lynx: Lynx lynx L.) were summed. Ungulate numbers may be underestimated (about 10\% by expert knowledge) because some animals may not have moved during the survey, and the predators could be overestimated because animals move between districts.

In Germany, populations of roe deer (Capreolus capreolus L.), fallow deer (Dama dama L.), red deer (Cervus elaphus L.), and mouflon (Ovis orientalis musimon) were assessed (Table 1) by spotlight counting and by expert estimates of the forest service (Tottewitz et al. 1996, Heinze et al. 2011). Two spotlight counts 
Table 1 Ruminant equivalent units and numbers of individual deer species in the Hainich region and in Romania (deer number $/ \mathrm{km}^{2}$ ). The German numbers were assessed by repeated spotlight counts, except for Westerwald where the numbers are based on expert knowledge of the local forest service. The Romanian numbers are based on winter track counts. The table shows averages \pm standard deviations

\begin{tabular}{|c|c|c|c|c|c|c|c|}
\hline & & $\begin{array}{l}\text { Ruminant } \\
\text { equivalent } \\
\text { units }\end{array}$ & Roe deer & $\begin{array}{l}\text { Fallow } \\
\text { deer }\end{array}$ & Red deer & Mouflon & $\begin{array}{l}\text { Wolf, Bear, } \\
\text { Lynx }\end{array}$ \\
\hline \multirow[t]{4}{*}{ Romania } & $\mathrm{NE}$ & $0.5 \pm 0.4$ & $1.0 \pm 0.6$ & 0 & $0.2 \pm 0.3$ & 0 & $0.06 \pm 0.1$ \\
\hline & Central & $0.4 \pm 0.3$ & $0.9 \pm 0.7$ & 0 & $0.2 \pm 0.3$ & 0 & $0.08 \pm 0.2$ \\
\hline & South & $0.5 \pm 0.3$ & $1.0 \pm 0.6$ & 0 & $0.2 \pm 0.2$ & 0 & $0.08 \pm 0.1$ \\
\hline & Age-class Forest & & & & & & \\
\hline \multirow[t]{4}{*}{ Germany } & Mühlhausen & $8.4 \pm 1.2$ & $27.0 \pm 1.8$ & $3.3 \pm 2.3$ & 0 & & 0 \\
\hline & Westerwald & 4.0 & 7.0 & 0.0 & 1.2 & 3.2 & \\
\hline & Selectively cut & $7.6 \pm 1.7$ & $17.0 \pm 0.4$ & $4.2 \pm 0.1$ & $1.2 \pm 1.7$ & 0 & 0 \\
\hline & Unmanaged & $8.7 \pm 2.0$ & $7.4 \pm 1.3$ & $3.1 \pm 0.9$ & $5.3 \pm 1.9$ & 0 & 0 \\
\hline
\end{tabular}

were carried out in the early evening and after dawn in spring and autumn of 2008. 100 watt spotlights were used along a total of 40 $\mathrm{km}$ of forest road for each management type. A comparison of the spotlight counts with other methods of deer density assessments (counts of feces, counts of footprints in fresh snow) showed good agreement for red deer, but an underestimate of about $30 \%$ for roe and fallow deer (Heinze et al. 2011).

For both countries, the different ungulate species were aggregated into a weight-corrected "ungulate equivalent unit", based on average food consumption of red deer. Four roe deer or two fallow deer are assumed to graze the equivalent of one red deer - about $840 \mathrm{~kg}$ of dry matter on 100 ha over one winter (Hofmann et al. 2008).

\section{Data analysis}

Effects of stand development. Tree species richness changes with stand development, and it is crucial to separate effects of succession and browsing. In this study the large number of inventory plots probably covers most of the range of interactions between browsing, stand age, and environmental conditions.

As an approximation of the net effect of this species turnover in European temperate deciduous forest, we investigate the age distribution 272 of various tree species richness levels. Due to the frequency of biotic and abiotic disturbances, there is a right-sided frequency distribution of the number of inventory plots representing a certain canopy tree species number, with many observations of plots at low average tree age on a plot, and a decreasing number of observations with increasing age. To avoid any bias of sampling, in our analysis we determined the maximum age that was observed for a given species richness level. We observed that a high mean age of trees in a plot was reached only at low tree species richness (see Fig. 1), confirming the observations in primary stands of deciduous forest (Korpel 1995). High species richness was found only in young stands (Buschel \& Huss 2003). The implications of species losses during succession are emphasized in the discussion.

In the following, we describe the change in tree species richness of the canopy by a regression through the maximum age that was reached by each species richness level. Since there are numerous causes for the variation of tree species richness at plot level, we made sure that the regression of species richness at maximum age would not be affected by the number of observations in that diversity class. Thus, our regression describes community dynamics of deciduous forest under most undisturbed and favorable conditions as base line. 
We are aware that this is a dynamic boundary line of the net effect of species losses and gains. If a gap were formed by the loss of an old tree individual, an additional species may enter into the canopy, but the mean age of trees will decrease by a younger individual entering the canopy. If a species were lost during self thinning, species richness will decline and may reach a higher mean age of trees at continually increasing height. Thus, we observed a negative relationship between species richness in the canopy and the maximum mean age of trees per plot (represented by the three observations of maximum age of a given diversity level: red points in Fig. 1), forming a boundary-line of a scatter diagram of all study plots. There are numerous situations of lower diversity and age due to anthropogenic and natural disturbances, environmental conditions and deer browsing.

Interactions between biotic and abiotic factors determining canopy species richness. In this study we used generalized linear models and structural equation modeling to study the interactions between parameters and to separate effects of correlated variables.

In order to describe the overall browsing effect, we defined the variable "species loss" as the difference between the number of species in the canopy, or in $\mathrm{HC} 1$, minus the number of species present in $\mathrm{HC} 2$, because this are the stages, at which the main differentiation between plant individuals occur. For this analysis we neglected plots without any regeneration. The lack of any regeneration could be due to light conditions below dense canopies or due to browsing by deer or due to domestic animal grazing of seedlings. We cannot distinguish between these factors especially since plots without any regeneration occurred at the same basal area where other plots showed a maximum of regeneration (see Supplement Fig. S3). We excluded these "zero" sites lacking any regeneration because the complete absence of regeneration on a plot does not allow to inspecting changes.

Generalized linear models (R Development
Core Team 2010) were used to explore the relationship of management, canopy cover, and browsing on tree species richness in the regeneration layer, without accounting for the multiplicity of possible interactions between factors (see Supplement-Table S2). Since species numbers in $\mathrm{HC} 1$ and $\mathrm{HC} 2$ also represent a shift in time, situations occur where tree diversity was higher in $\mathrm{HC} 2$ than $\mathrm{HC} 1$. We excluded these few instances of negative numbers.

Structural equation modeling was used to explain species losses in the regeneration layer by the complex direct and indirect interactions between browsing and other parameters (Grace 2006). We performed separate analyses for the forest management types 'protected forest', 'selectively cut forest', and 'age-class forest' in Germany, and for 'selectively cut forest' and 'age-class forest' in Romania. Due to a low number of replicates, we were not able to perform structural equation modeling analyses with data from protected forests in Romania. The initial model was based on previous knowledge (literature, expert knowledge; see Fig. 4A), testing effects of the tree species number in the canopy, the percentage of Fagus in the canopy and light availability (exogenous variables) on browsing in age class 1 , tree density in age class 1 , and on species loss (endogenous variables). The initial model was improved by using "modification indices" (which are program functions indicating if adding new paths will improve the model fit) and stepwise removal of "unimportant relationships" (paths which were not significant and removal would improve the fit of the model); however, only "scientifically sound paths" (paths for which an established theory exists) were considered (Grace 2006). The adequacy of the models was determined through $\chi^{2}$ tests, AIC and RMSEA (Supplement-Table S3). Adequate model fits are indicated by a non-significant $\chi^{2}$ test $(P>0.05)$, low AIC and low RMSEA $(<0.05)$ (Grace 2006, Arbuckle 2010). Structured equation modeling was performed with IBM SPSS Amos 21.0.0 (Amos Development 

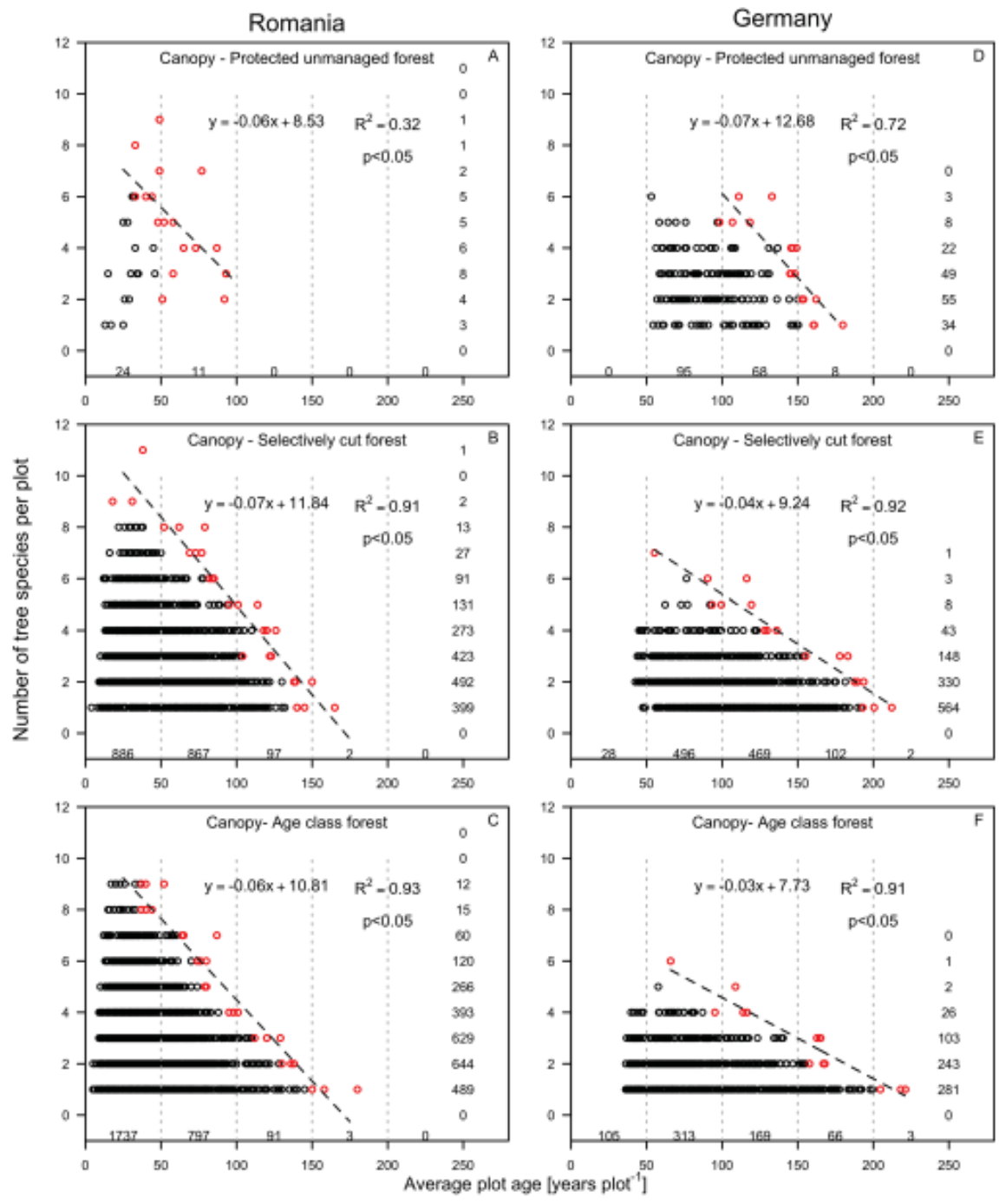

Figure 1 Scatter diagram of tree species per inventory plot in the canopy as related to average stand age for Romania (a) and Germany (b). The boundary line is a linear regression based on the diversity observations at the 3 highest ages for each diversity class (red dots). The numbers at the margin of the plot indicate the total number of dots in each row and column

Corporation; Meadville, PA, USA). Tree density in age class 1 was $\log 10$-transformed to allow for linear analyses. Scatter diagrams of the individual relations are summarized in the supplement (Supplement-Fig. S4). The results from simple regressions and structural equation models may differ, because structural equation models account for the co-variance structure of the tested variables and thus provide a more balanced picture of relationships in a multivariate context.

\section{Results}

\section{Species diversity in the canopy layer during succession}

The maximum number of tree species in the canopy decreased with stand age irrespective of the study region, the management or the dominant tree species (Fig. 1, boundary lines). In Romania, at plot scale, a maximum of 11 tree species were found in the canopy at early succession (age 40 to 50 years) in selec- 
tively cut forest (Fig. 1 A to C). The maximum number of species per plot is about $50 \%$ of the total number of dominant species in the region (see also Table 3). Despite this potentially high diversity on single plots, most plots had less than 3 species, irrespective of the type of management as indicated by the numbers inserted on the margins of Figure 1.

Old forest stands may contain multiple layers of trees. This causes an apparent low maximum age in Romania compared to regularly thinned age-class forests in Germany. For Romania, the loss of species with successional age as indicated by the slope of the boundary line was 0.6 to 0.7 species lost for every 10 years of increasing age.

In Germany (Fig. 1D to F), the maximum number of species per inventory plot was 7 , which was lower than in Romania, mainly due to the count of genera in Quercus, Tilia, Ulmus and Sorbus under-representing tree species richness. At plot-scale, the total number of species was surprisingly similar between Romania and Germany.

The loss of species by succession in protected forest in Germany was similar to Romania (0.7 species lost every 10 years). The loss was lower in managed German forests $(0.3$ to 0.4 species per 10 years) at lower maximum diversity. In both countries, Fagus sylvatica is the only species remaining after 150 years in Romania and 200 years in Germany at plot scale (Section 3.5 gives the regional loss of tree species). Thus, species are lost during succession, and in the following we will explain the additional effects of browsing and grazing, which reduces species diversity at the stage of regeneration.

\section{Species diversity in the regeneration layer}

All species may regenerate in the lowest layer (HC1) independent of stand age and species richness in the canopy (Supplement-Fig. S5). Despite this potential for regeneration, the maximum species number in the regeneration layer was always lower than in the canopy.

In Romania (Fig. 2), the average species number in the lower regeneration layer (including plots without regeneration) was about 1 species, with a maximum of 5 in protected forest to 8 and 9 species in managed forests. A significant decrease in species number between $\mathrm{HC} 1$ and $\mathrm{HC} 2$ was observed (ANOVA, $p<0.00234$ ), but species numbers in the regeneration layer increased again in $\mathrm{HC} 3 \mathrm{com}-$ pared to HC2 (ANOVA, $p<0.00234$ ).

In Germany, the average number of species in $\mathrm{HC} 1$ was 2 , while the maximum number reached only 5 , as compared to 7 in the canopy, in part due to the count of genera (not species) in Quercus, Tilia, Ulmus and Sorbus. In contrast to Romania, there was a significant trend (ANOVA, $p<0.05$ ) of decreasing species number when comparing $\mathrm{HC} 1$ with $\mathrm{HC} 2$ and HC3.

\section{Browsing effects on regeneration}

The fresh (last winter) loss of terminal bud was considered as a parameter to quantify the effects of browsing and grazing (SupplementTable S4). In Romania, browsing affected only about 3 to $6 \%$ of the total number of trees in $\mathrm{HC} 1$ and $\mathrm{HC} 2$ of rotation and selectively cut forests, but reached $10 \%$ in $\mathrm{HC} 2$ of protected forests. In contrast, in Germany, browsing affected 16 to $39 \%$ of the terminal buds in $\mathrm{HC} 1$ and $\mathrm{HC} 2$ of rotation and selectively cut forests, but reached levels $>40 \%$ in protected forest. Browsing rate was lower in $\mathrm{HC} 3$ as these trees are too tall to be browsed by roe deer.

The loss of the terminal bud by browsing or grazing was not shared equally among species and not related to the density of the respective species (Table 2). Fagus sylvatica exhibited the highest plant density in HC1 both in Romania and Germany. The density of Fraxinus excelsior and Acer pseudoplatanus was higher in Germany than in Romania, while Carpinus betulus, Ulmus spp. and Acer campestre reached higher density in Romania than in 

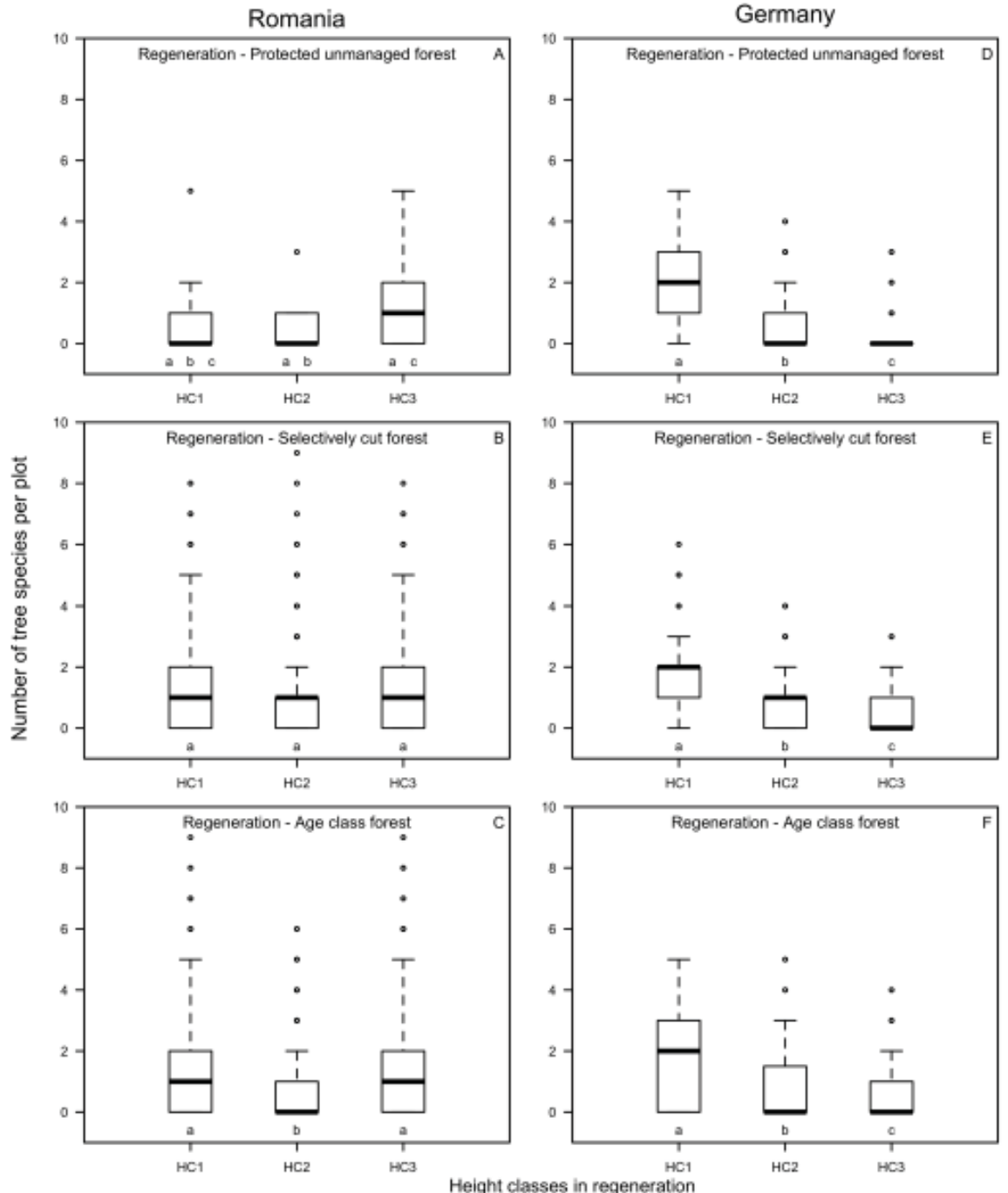

Figure 2 Box diagrams of tree species in the regeneration layers of Height Class 1 to 3 for Romania (left) and Germany (right). The box represents the $50 \%$ quantile of the data around the median. The lines (bars) represent the variability as represented by the factor 1.5 of the quantile range. Outliers beyond this range are plotted as individual data points. Plots without regeneration were included in the computation. The small letters below the columns indicate significant difference $p<0.05$ (ANOVA)

Germany.

In Romania, only $2 \%$ of Fagus sylvatica individuals lost the terminal bud, as compared to $12 \%$ of the individuals of more palatable species such as Sorbus aucuparia and 6 to 7\% of individuals of Fraxinus excelsior and Acer pseudoplatanus. In Germany, the fraction of individuals that lost the terminal bud was up to ten times higher than in Romania. Despite its dominance, only $12 \%$ of the Fagus sylvatica individuals lost their terminal bud. This con276 trasts to 60 to $77 \%$ of the individuals of Fraxinus excelsior and Acer pseudoplatanus, and to about 20 to $40 \%$ of all other associated species individuals that lost their terminal bud in a single year.

For both countries, the relationship between species numbers and associated browsing intensity in $\mathrm{HC} 1$ and $\mathrm{HC} 2$ indicates that the highest number of species was observed only at low browsing intensity (Fig. 3). The boundaries of the scatter plots (green dots in Fig. 
Table 2 Density of individual tree species measured in Height Class 1 (the numbers are small because plots where a given species does not occur or without regeneration are included and contribute with 0 ) and the fraction of individuals that lost the terminal bud in 2008. Only species with more than $1 \%$ density are shown. The numbers average across 3 management types \pm standard deviations

\begin{tabular}{|c|c|c|c|c|}
\hline & \multicolumn{2}{|l|}{ Romania } & \multicolumn{2}{|l|}{ Germany } \\
\hline & $\begin{array}{l}\text { Density } \\
\text { (individuals } \\
\mathrm{m}^{-2} \text {, av. } \pm \text { s.d.) }\end{array}$ & $\begin{array}{l}\text { Browsed } \\
\text { individuals in \% of } \\
\text { total individuals of } \\
\text { that species (av. } \pm \\
\text { s.d.) }\end{array}$ & $\begin{array}{l}\text { Density } \\
\text { (individuals } \\
\mathrm{m}^{-2} \text {, av. } \pm \text { s.d.) }\end{array}$ & $\begin{array}{l}\text { Browsed } \\
\text { individuals in \% of } \\
\text { total individuals of } \\
\text { that species (av.. } \\
\text { s.d.) }\end{array}$ \\
\hline$\overline{F a g u s ~ s y l v a t i c a}$ & $0.589 \pm 1.247$ & $2 \pm 11$ & $0.829 \pm 0.236$ & $12 \pm 5$ \\
\hline Fraxinus excelsior & $0.044 \pm 0.249$ & $7 \pm 24$ & $0.535 \pm 0.227$ & $60 \pm 16$ \\
\hline Acer pseudoplatanus/ & $0.034 \pm 0.191$ & $6 \pm 23$ & $0.370 \pm 0.332$ & $77 \pm 33$ \\
\hline Acer platanoides & $0.017 \pm 0.158$ & $5 \pm 22$ & $0.021 \pm 0.012$ & $30 \pm 18$ \\
\hline Carpinus betulus & $0.360 \pm 1.103$ & $4 \pm 18$ & $0.016 \pm 0.016$ & $72 \pm 38$ \\
\hline Tilia spec & $0.060 \pm 0.286$ & $5 \pm 21$ & $0.010 \pm 0.012$ & $21 \pm 6$ \\
\hline Ulmus spec & $0.041 \pm 0.200$ & $4 \pm 18$ & $0.005 \pm 0.002$ & $41 \pm 29$ \\
\hline Acer campestre & $0.081 \pm 0.321$ & $5 \pm 20$ & $0.002 \pm 0.002$ & $29 \pm 30$ \\
\hline Sorbus aucuparia & $0.006 \pm 0.101$ & $12 \pm 32$ & $0.001 \pm 0.002$ & $41 \pm 18$ \\
\hline
\end{tabular}

Note. Abbreviations: av. - average, s.d. - standard deviation.

3) show a significant decrease of the species number in the regeneration layer with increasing browsing intensity. The species loss was largest when Fagus sylvatica was dominant, irrespective of the type of management.

The recorded regional differences in success of regeneration in $\mathrm{HC} 1$ could be related to the age-class distribution of the canopy. In Romania, about two-thirds of all stands were less than 50 years old (average age of all canopy trees per plot), while only $5 \%$ of the stands were aged less than 50 years in Germany. However, browsing in different height classes was not related to the average canopy age of the inventory plot (Supplement-Fig. S6). Browsing was highly patchy: irrespective of stand age, there were a large number of plots without browsing or with $100 \%$ browsing.

In this study it was not possible to investigate the causes for lack of any regeneration on inventoried plots - e.g., the complete consumption and failure of seedlings. In a separate analysis of the density of regeneration in relation to basal area (Supplement-Figure S3) we show that plots without any regeneration are not observed at highest basal area, but at inter- mediate stages of succession where on other plots a maximum of regeneration was reached. Also, plots without any regeneration were only observed in Germany (see also Supplement-Table S1). Thus, the complete absence of regeneration appears to be related to deer browsing.

\section{Factors contributing to species loss in the regeneration layers}

General linear models already indicate that the loss of species number in the regeneration layer of $\mathrm{HC} 2$ was related to ungulate browsing with higher levels of significance in Germany as in Romania (Supplement-Table S2).

The complicated interactions between stand parameters and browsing become apparent in structural equation models (see Fig. 4A for the initial model) which fit the data well in all five cases where analyses were possible (all $\chi^{2}$ tests $P>0.06$ ). We were able to explain 11 to $13 \%$ of the variance in species loss in Romania (Fig. 4B and C) and 8 to $26 \%$ in Germany (Figure 4D, E and F). Overall, the structural equation models reveal that sapling density 

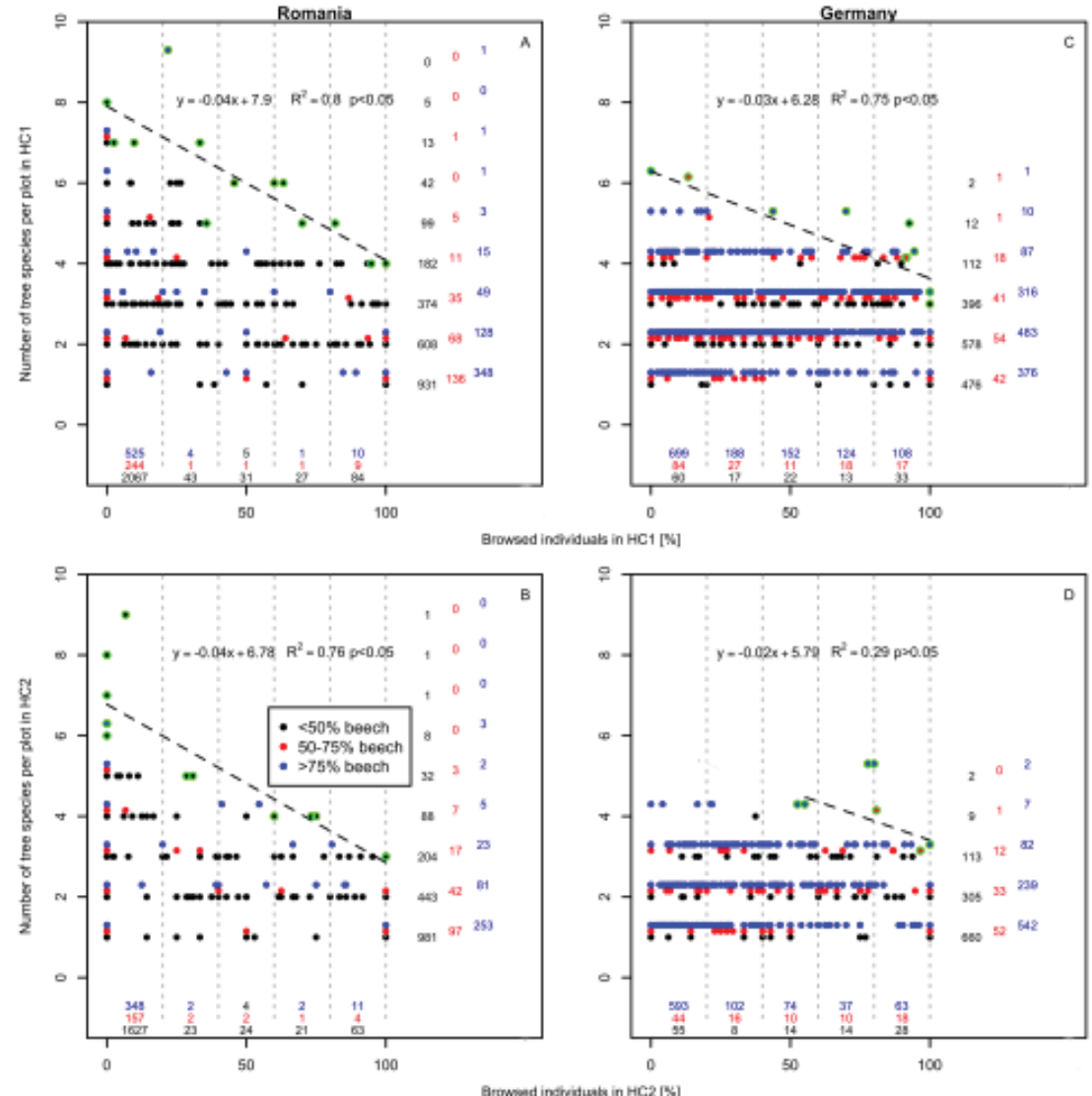

Figure $3 \mathrm{Scatter}$ diagram of number of tree species per plot in $\mathrm{HC} 1$ and $\mathrm{HC} 2$ as related to the relative number of browsed individuals (\% of total number of individuals) for stands with different dominance of Fagus. The numbers at the margin of the plot indicate the total number of dots in each row and column grouped according to the presence of Fagus

in $\mathrm{HC} 1$ and browsing in $\mathrm{HC} 1$ were the most consistent and significant predictors for species loss both in Romania and Germany. While tree species number in the canopy was only significantly and positively associated with species loss in Romania and in age-class forest in Germany, light had only inconsistent effects on species loss (two significant relationships in selectively cut forests and age-class forests in Germany). The percentage of Fagus in the canopy increased species loss in Germany through mechanisms not related to light availability and tree density in $\mathrm{HC} 1$, but this was only significant in protected forests.

\section{Regional effects of browsing and manage- ment on tree species composition}

The effects of browsing at plot scale do not include the effects on regional tree flora, and the large-scale effects of browsing and management on tree species composition can only be demonstrated in a regional comparison (Table 3). In Romania, about 20 species are found in the canopy, with a lower number of species in protected forests, due to the lower number of sampling points (see Fig. S1). For this region, the loss of species in the regeneration layer was 10 to $30 \%$, with a maximum loss in $\mathrm{HC} 2$ of protected forests.

In Germany, the regional loss of species was larger than in Romania. Considering that Tilia, Quercus, Sorbus and Ulmus contained more 

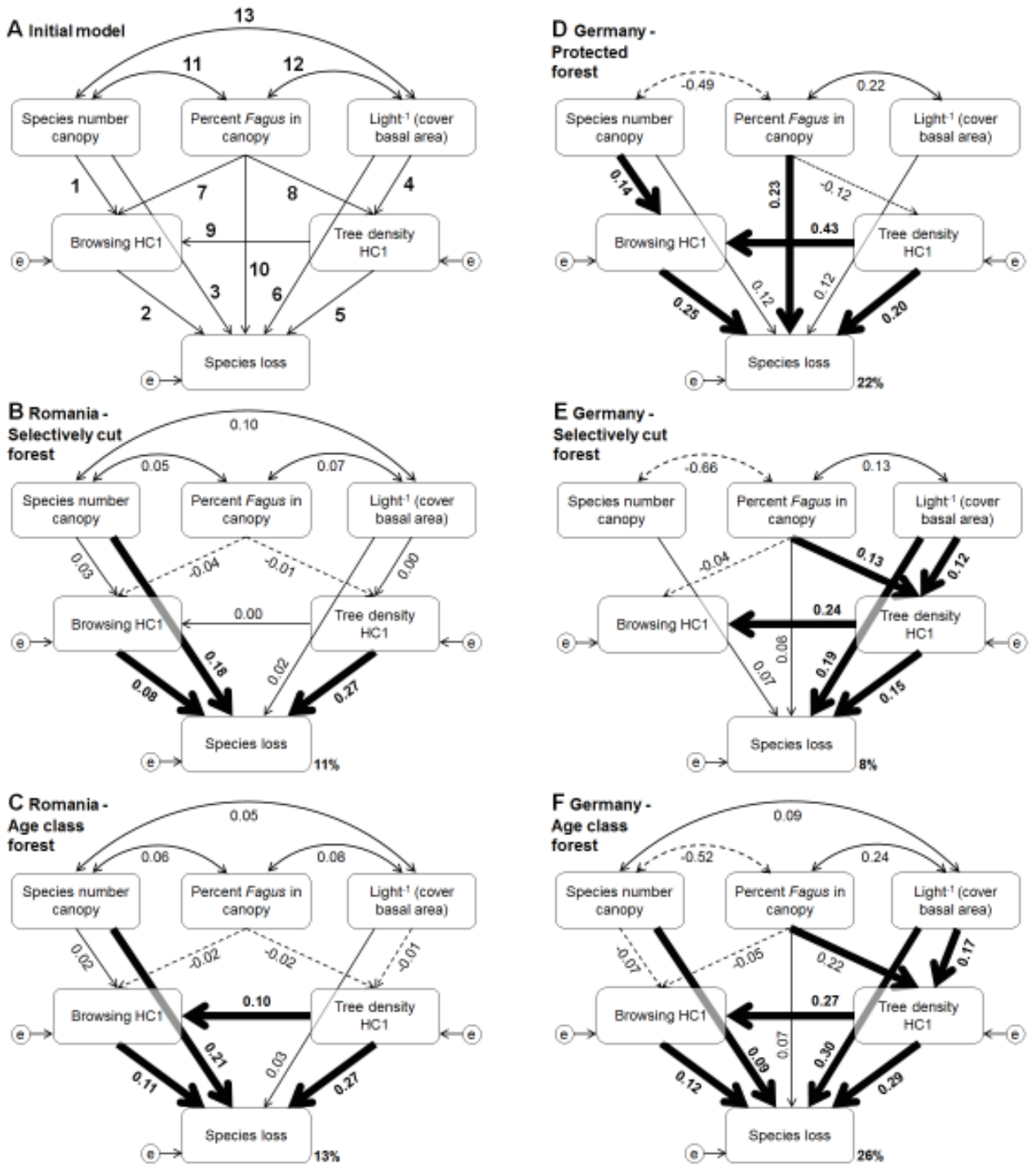

Figure 4Structural equation models on the drivers of extinction (loss of species in the regeneration of different height classes). A. Initial structure of the model. Numbers on arrows indicate references to these hypotheses: 1 Reimoser \& Gossow (1996), Heinze et al. (2011); 2 Gill \& Beardall (2001), Tanentzap et al. (2011), Allombert et al. (2005), Jorritsma et al. (1999), Lessard et al. (2011); 3 Ellenberg et al. (1978); 4 Ammer et al. (1996); 5 Luyssaert et al. (2008); 6 Horsley et al. (2003), Petrițan et al. (2009), Ammer et al. (1996); 7 Van Hees et al. (1996), Heinze et al. (2011), Gill (2006), Horsley et al. (2003); 8 Van Hees et al. (1996); 9 Gill (2006), Horsley et al. (2003); 10 to 13. Buschel \& Huss (2002). B. Romania: selectively cut forest. C. Romania: age class forest. D. Germany protected forest. E. Germany selectively cut forest. F. Germany: age class forest. There were too few observation points to meet the model requirements for Romania protected forest. Labels: species number canopy: non-beech species in the canopy; Light $^{-1}$ : basal area of canopy trees as surrogate for light attenuation, Browsing $\mathrm{HCl}$ : browsed individuals in percent of total individuals in $\mathrm{HC} 1$; Extinction: loss of species comparing HC2 and $\mathrm{HC} 1$ (Romania) and canopy and $\mathrm{HC} 1$ (Germany), respectively, e: error terms, double-headed arrows indicate correlations between error terms or relationships lacking clear hypotheses. Width of the arrows indicated the strength of the causal influence: bold arrows indicate significant standardized path coefficients $(p<0.05)$, fine arrows indicate non-significant path coefficients $(p>0.05)$; solid arrows indicate positive relationships, dashed arrows indicate negative relationships (only directed arrows). Standardized path coefficients are given on arrows (see Supplementary-Table S2 for more information). 
Table 3 The number of tree individuals per square meter in the canopy, the smallest regeneration layer ( $\mathrm{HC} 1)$ and the tallest regeneration layer ( $\mathrm{HC} 3)$ of selectively cut forest, age-class forest and protected forest in Germany (a) and of non-Fagus dominated and Fagus dominated forest in Romania (b). The numbers are very low for most species due to the absence of any individual on many plots. Bold letters highlight the loss of species

\begin{tabular}{|c|c|c|c|c|c|c|c|c|c|}
\hline Romania & Selective & ly Cut $F$ & orest & Age-clas & s-forest & & Protectec & $\mathrm{d}$ forest & \\
\hline Species & Canopy & $\mathrm{HC} 1$ & $\mathrm{HC} 3$ & Canopy & $\mathrm{HC} 1$ & HC3 & Canopy & $\mathrm{HC} 1$ & $\mathrm{HC} 3$ \\
\hline Fagus sylvatica & 0.017 & 0.478 & 0.108 & 0.020 & 0.259 & 0.116 & 0.017 & 0.280 & 0.024 \\
\hline s excelsior & $<0.001$ & 0.018 & 0.004 & 0.001 & 0.018 & 0.007 & 0.003 & 0.014 & 0.063 \\
\hline & $<0.001$ & 0.024 & 0.003 & $<0.001$ & 0.013 & 0.003 & 0.003 & 0.024 & 0.000 \\
\hline Tilia (2 species) & $<0.001$ & 0.025 & 0.008 & $<0.001$ & 0.026 & 0.018 & $<0.001$ & 0.000 & 0.039 \\
\hline Acer platan & $<0.001$ & 0.011 & 0.001 & $<0.001$ & 0.014 & 0.005 & 0.003 & 0.080 & 0.011 \\
\hline Carpinus betulus & 0.013 & 0.195 & 0.081 & 0.018 & 0.244 & 0.153 & .019 & 0.201 & 0.022 \\
\hline 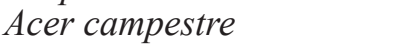 & 0.001 & 0.029 & 0.006 & 0.002 & 0.027 & 0.011 & $<0.001$ & 0.000 & 0.050 \\
\hline Ulm & $<0.001$ & 0.008 & 0.003 & 0.001 & 0.008 & 0.005 & 0.001 & 0.014 & 0.004 \\
\hline Quer & 0.010 & 0.351 & 0.010 & 0.0 & 0.242 & 0.012 & & 0.000 & 0.007 \\
\hline Sorb & 0.000 & 0.000 & $<0.001$ & 0.0 & 0.000 & 0.000 & 00 & 0.000 & 0.000 \\
\hline Larix & $<0.001$ & 0.000 & 0.000 & $<0.001$ & 0.000 & 0.000 & 0.000 & 0.000 & 0.000 \\
\hline Prur & $<0.0$ & 0.012 & 0.003 & & 0.009 & 0.004 & & 0.021 & 0.000 \\
\hline Betu & $<0.0$ & 0.006 & 0.0 & 0.0 & 0.001 & 0.004 & 00 & 0.000 & 0.000 \\
\hline alix & $<0.0$ & 0.000 & 0.001 & & 0.001 & 0.006 & & 0.000 & 0.000 \\
\hline & 0.000 & 0.000 & 0.000 & & 0.000 & 0.000 & $<0.001$ & 0.000 & 0.000 \\
\hline Popt & 0.001 & 0.003 & 0.003 & 0.001 & 0.005 & 0.007 & $<0.001$ & 0.000 & 0.000 \\
\hline Spe & 20 & 18 & 18 & 23 & 18 & 17 & 10 & & 10 \\
\hline Dof & & & $10 \%$ & & & $26 \%$ & & $30 \%$ & $0 \%$ \\
\hline & & & & & & & & & \\
\hline & 0.027 & 1.099 & 0.360 & 0.046 & 0.674 & 0.168 & 0.034 & 0.712 & 0.051 \\
\hline & & 0.510 & & & 0.774 & & & & 0.080 \\
\hline & & 0.144 & 03 & & 0.215 & 0.0 & 03 & 0.752 & 0.037 \\
\hline & $<0.001$ & 0.006 & 0.0 & $0 .($ & 0.002 & 0.001 & 02 & 0.023 & 0.010 \\
\hline & & 0.035 & & & 0.014 & 0.0 & 01 & 0.013 & 0.001 \\
\hline & 1 & 0.017 & $<0.001$ & $<0.0$ & 0.002 & & & 0.034 & $\mathbf{0 , 0 0 0}$ \\
\hline & & & & & $<0.001$ & & & $<0.001$ & $\mathbf{0 , 0 0 0}$ \\
\hline & 1 & 0.006 & 0,0 & $<0.001$ & 0.003 & $<0.0$ & & 0.007 & $\mathbf{0 , 0 0 0}$ \\
\hline & 0.001 & $<0.001$ & 0,0 & & $<0.001$ & & & 0.000 & 0,000 \\
\hline & & $<0.001$ & & & & & & 0.000 & \\
\hline & 0.00 & $\mathbf{0 . 0 0 0}$ & 0,0 & $<0.001$ & $<0.001$ & & $<0$ & 0.000 & 0,000 \\
\hline & & $<0.0$ & & & & & & & 0,000 \\
\hline & 1 & & & & & & & 0.000 & $\mathbf{0 , 0 0 0}$ \\
\hline & $<0.001$ & 0.000 & & & 0.000 & & & 0.000 & 0,000 \\
\hline & & $<0.001$ & & & & & & 0.000 & 0,000 \\
\hline & 0.000 & $\mathbf{0 . 0 0 0}$ & 0,000 & $<0.001$ & 0.000 & 0,000 & 0.000 & 0.000 & $\mathbf{0 , 0 0 0}$ \\
\hline & 20 & 18 & & 21 & 16 & 10 & 18 & & \\
\hline & & & $65 \%$ & & & $52 \%$ & & & $67 \%$ \\
\hline
\end{tabular}

than one species, the regional tree diversity of Thuringia is 22 tree species. The canopy of the selectively cut, age-class and protected forest contained a total of 20,21 and 18 tree species respectively. The total number of species in $\mathrm{HC} 3$ decreased to 7, 10 and only 6 (52 to $67 \%$ loss) in the selectively cut, age-class and protected forest, respectively.

\section{Discussion}

\section{Decline of tree species diversity during suc- cession versus browsing}

Tree species diversity is affected not only by environmental forces, but also by competition between species during succession, and both processes may be additive or compensating. In this context it appears crucial to quantifying the 
natural community dynamics of the deciduous forest, where species may not only be lost, but also be gained during succession. Based on a meta-analysis, Horn (1974) claimed that the diversity of the "climax" should be lower than the diversity of preceding stages. However, the trend seems to depend on the species reservoir of late successional species. Species numbers increased with succession in tropical forests (e.g. Wittmann et al. 2006), but decreased in boreal forest (e.g. Schoonmaker \& McKee 1988), and this may depend on the geological history. Contrasting to deciduous forests in North America and East Asia, European forests were impoverished during the Pleistocene (Schulze et al. 1996).

In our study, the boundary line in Fig. 1 represents the upper level of attainable tree diversity for a given developmental stage under a broad range of conditions. We observed a decline to the level of one remaining species due to the species-specific ability to grow in height. In Europe, Fagus sylvatica becomes a "monopolist" (in the sense of Horn 1974), because it is the tallest species, reaching more than $40 \mathrm{~m}$ in height, overtopping all other associated canopy species on average by 5 to 10 m (Schulze et al. 2010). In addition, Fagus sylvatica is more capable than any other associated tree species for rapid lateral growth, closing any canopy gap in a short period of time. Height and lateral growth of Fagus sylvatica explain the observation of monotypic old growth stands (Petrițan et al. 2014, Korpel 1995). In the present large dataset, we never observed a species-rich old stand. The species "reservoir" of European deciduous forest does not contain an old-growth competitor for $\mathrm{Fa}$ gus, except, maybe, for Abies alba at higher altitudes.

All tree species had the possibility of regenerating in the lowest layer ( $\mathrm{HC} 1)$, independent of canopy age and the species richness in the canopy. Despite this potential for regeneration, our study shows that the maximum species number in the regeneration layer was always lower than in the canopy (comparing Fig. 1 with Fig. 2), and this was partly explained by browsing. Our data provide evidence contradicting the initial hypothesis that in European deciduous forests ungulate browsing may increase diversity (in the sense of Harper 1977). Browsing appears to enhance the established pattern of species diversity reduction from species-rich young communities towards late successional mono-specific stands (Mayer 1984, Begon et al. 1990). This apparent enhancement of succession distorts the community dynamics and tree diversity in earlier stages of succession. A forest management effect on the rate of tree species decline is not apparent, contradicting our second general hypothesis. Even though the affected species can recover, they lose the competitive advantage of early height growth, i.e. they are overgrown and shaded out by the non-grazed species, mainly Fagus sylvatica.

\section{Other factors explaining species loss in regeneration}

Our observation contrasts studies which regard shade tolerance as the main factor regulating density and diversity of regeneration, with Fagus being "apparently" the most shade tolerant species (e.g., Petrițan et al. 2009, von Lüpke 2005). Many of these observations were made in stands without any protection against browsing. In our study, the structural equation analysis detected a more consistent effect of browsing than of light, confirming Abs et al. (2008) who showed that the light requirements of Fagus are very similar to those of Tilia and Ulmus, and that shade tolerance of Acer pseudoplatanus and Acer platanoides even exceeds the shade tolerance of Fagus. If protected from browsing, non-Fagus species would become dominant even under conditions of shade (Striepen 2000, Caquet et al. 2009). In our study, Fagus had already become dominant by the third height class, having totally suppressed Acer platanoides. Overall, $77 \%$ of $A$. plata- 
noides individuals were browsed in Germany in a single season. In a fencing experiment of our study region, Schulze (2014) showed that even Fagus suffers from browsing: tree height was 4 to 6 meters taller in fenced versus unfenced areas four years after fencing, and nonFagus species were dominant over Fagus in the sun and in the shade. Modry et al. (2004) already concluded that browsing is the main factor confounding shade tolerance studies. Obviously, the "apparent" superior shade tolerance of Fagus results from its lower speciesspecific palatability to roe deer (Holt 1977, Pépin et al. 2006).

We did not investigate the effects of deer on seedlings (Gill \& Beardall 2001). Thus, the effects of deer are likely to be underestimated. The variable number of plots without any regeneration, as well as the reduction in species number between the canopy and $\mathrm{HC} 1$, is probably associated with deer browsing on seedlings as fencing experiments indicate (Striepen 2000, Schulze 2014). Thus, based on an extensive monitoring of more than $>6,500$ plots we conclude that the species diversity in the tall regeneration layer is up to $67 \%$ lower than in the canopy, with a large number of species being effectively lost at regional scale, with ungulate browsing playing a significant role across different forest management types.

\section{Regional differences and deer management}

Our initial hypothesis was that the level of browsing pressure in Romania is "more natural", because of the existence of large predators which, together with illegal hunting, reduces the number of ungulates. In contrast to our expectations and despite a low deer population, however, major species losses in regeneration were also found in Romania, the decline being most prominent in $\mathrm{HC} 1$ and $\mathrm{HC} 2$. The increase in species numbers in $\mathrm{HC} 3$ may indicate that the process is a recent occurrence, affecting $\mathrm{HC} 1$ more than $\mathrm{HC} 3$, and may not have even existed when $\mathrm{HC} 3$ was at the age of $\mathrm{HC} 1$. The decline in tree species in $\mathrm{HC} 1$ as compared to $\mathrm{HC} 3$ and the canopy cannot be explained by deer only. It appears be related to a change in land management following the political changes in Romania in 1990. A decline in forest-policing enhanced illegal forest grazing, which is now a common practice. Obviously, separating the effects of grazing and browsing needs further investigation.

The other important finding of this study concerns Germany: the largest effect of browsing was observed in protected areas (see also Mitchell \& Kirby 1990). This observation is supported by the repeated grid-based inventories in Hainich National Park (Nationalpark Hainich 2013) showing the decline of density in non-Fagus species. The core area of the $\mathrm{Na}-$ tional Park is not being hunted. Our observations question the concept of "letting nature take its course". The high deer population in Germany in general, and in protected areas specifically, are anthropogenic: natural predators have been eliminated, while adjacent agricultural land provides an additional source of food. The region is too small for "natural" development.

The high browsing intensity in Germany is confirmed by government assessments. In Thuringia, $57 \%$ of non-Fagus species are browsed annually (Thüringen Forst 2010). The roe deer population increased by at least $30 \%$ between 1980 and 2000 (Milner et al. 2006). The German revolution in the $19^{\text {th }}$ century and subsequent wars repeatedly created periods of low deer density, favoring tree regeneration and the development of the present species-rich canopies (Schulze et al. 2010). All the investigated forest management systems in Germany, including nature protection, suffer the same effects of deer browsing and tree species losses (see also Reimoser \& Gossow1996, Gordon et al. 2004). Based on our results, the only possble way of mitigation is a change in "the legal framework of" deer management.

The structural equation modeling explains 11 to $13 \%$ of the species loss in Romania and 8 
to $26 \%$ in Germany, based on freshly browsed terminal buds of the winter season prior to the inventory work. Species loss is based on a single season of freshly affected terminal buds. Considering, that about $10 \%$ of the non-Fagus species are lost by browsing of a single season, all non-Fagus species could be lost within 10 years. This is in fact the time to move from $\mathrm{HC} 1$ to $\mathrm{HC} 2$. Compared to the estimates by the German State Forest administrations, our estimates are still conservative. We did not investigate multiple browsing, but only fresh bites. All Acer individuals show single or multiple browsing marks in Germany, and most of them cannot recover to an extent that they could compete with un-browsed neighbors. Thus, the browsed individuals are eventually lost from the regeneration. Unexpectedly, the number of affected terminal buds was high in Romania, despite relatively low deer populations. Obviously, the effects of grazing by domesticated animals leads to the same effects in Romania, as high deer populations in Germany.

\section{Ecosystem consequences of tree diversity losses to other organisms}

Losses of tree species may cause significant cascading effects on other species in deciduous forest ecosystems. These indirect effects are wide-ranging, including songbirds (Allombert et al. 2005), wildcat populations (Lozano et al. 2007), insect populations (Brousseau et al. 2013), and even belowground communities (Lessard et al. 2012). It is inherently difficult to include other organisms in grid-based inventories and therefore ecosystem perspectives have not been sufficiently recognized in the past. It emerges that the damage caused by excess deer populations goes far beyond the loss of tree species. Here we draw attention to macrolepidoptera (Walentowski et al. 2010) assuming that the associated species that are indicated as a loss in Table 3 would in fact be lost at stand scale in the future.

Macrolepidoptera rely on a special resource or tree species for their development in the caterpillar stage (stenoecic), or they can use a broad spectrum of plants as hosts (euryoecic). The number of these species that can feed on Fagus indicate the importance of non-Fagus species (Table 3). The potential loss of macrolepidoptera due to the loss of a tree species may be calculated as the number feeding on this tree species minus the number of species that can also feed on Fagus. Thus, the following numbers estimate the maximal species loss under the condition that only Fagus survives, which is the case in heavily browsed natureprotected areas of Germany. The number of potentially endangered stenoecic macrolepidoptera species ranges between 8\% (Carpi$n u s$ ) and $80.5 \%$ (Salix). The total number of species potentially lost in a pure Fagus forest compared to a mixed forest is 537 out of 800 stenoecic species (67\% loss). As there are overlaps of host tree species for macrolepidoptera, the effect will be lower for the remaining mixture of species shown in HC3 of Table 4. However, the maximum number would represent as much as $55 \%$ of the macrolepidoptera of Central Europe (Hacker 1998). The present estimate of potentially endangered macrolepidoptera is still incomplete, because Sorbus (other than S. aucuparia), Pyrus and Malus, and which are endangered genera, have not yet been investigated with respect to their butterfly fauna. Most likely the loss of associated tree species will result in major losses of many additional taxa that are yet to be studied in detail. Similar effects were observed with xylobiontic beetles ( $45 \%$ of the taxa depend on non-Fagus species, Müller et al. 2005) and molluscs (44\% require non-Fagus species, Thoms 2010). This wide range of organismic groups indicates that the expected effects are indeed disturbing, since plant species diversity emerged as the "back-bone" of the associated diversity of heterotrophic organisms (Scherber et al. 2010). Thus, this browsing-induced tree species loss is likely to contribute to a major biodiversity loss across Europe. 
Table 4 Butterfly species numbers feeding as caterpillar on various tree species. The data in brackets of the columns with "Total" represent the number of stenoecic species that can only feed on that species. The last column lists the number of species that can also feed on Fagus (euryoecic). Sorbus is represented by Sorbus aucuparia only. Prunus is represented by Prunus avium

\begin{tabular}{lllllllr}
\hline & Papilionidae & $\begin{array}{l}\text { Bombyces/ } \\
\text { Sphingidae }\end{array}$ & Noctuidae & Geometridae & $\begin{array}{l}\text { Total } \\
\text { (stenoecic) }\end{array}$ & $\begin{array}{l}\text { Species } \\
\text { remaining } \\
\text { on Fagus }\end{array}$ & $\begin{array}{l}\text { Number of } \\
\text { potentially } \\
\text { lost species }\end{array}$ \\
\hline Quercus & 2 & 55 & 63 & 59 & $179(30)$ & 46 & $133(74.3 \%)$ \\
Betula & 4 & 33 & 23 & 60 & $120(3)$ & 27 & $93(77.5 \%)$ \\
Salix & 7 & 35 & 68 & 59 & $169(2)$ & 33 & $136(80.5 \%)$ \\
Populus & 1 & 30 & 39 & 17 & $87(4)$ & 21 & $66(75.9 \%)$ \\
Tilia & 0 & 15 & 24 & 32 & $71(3)$ & 23 & $48(67.6 \%)$ \\
Ulmus & 4 & 5 & 27 & 21 & $57(2)$ & 13 & $44(77.2 \%)$ \\
Sorbus & 2 & 5 & 9 & 7 & $21(0)$ & 16 & $5(23.8 \%)$ \\
Fraxinus & 1 & 3 & 8 & 7 & $19(0)$ & 17 & $2(10.5 \%)$ \\
Acer sp. & 0 & 4 & 8 & 21 & $33(1)$ & 25 & $8(24.5 \%)$ \\
Carpinus & 0 & 5 & 11 & 9 & $25(0)$ & 23 & $2(8.0 \%)$ \\
Prunus & 1 & 7 & 4 & 7 & $19(0)$ & Unknown & Unknown \\
\hline
\end{tabular}

\section{Legal implications of hunting and manage- ment}

Even though we have not studied the legal framework of hunting and forest management, we feel that the current situation has historic roots in feudalistic property rights and it can therefore only be altered by changes in that legal framework. Hunting and grazing versus forest production represents a classic conflict of forestland rights and interests (Hellström \& Reunala 1995, Niemelä et al. 2005). Hunting legislation in most nations of Europe is part of a long-established legal framework of property rights, in which for different reasons the hunting rights have been separated from the attributes of land ownership. That per se is a source of conflict between landowners and hunting associations. It is frequently assumed that this conflict also extends to the hunting and biodiversity-conservation interests. However, this assumption should be questioned, and the many nature conservation policies based on non-intervention, as is the case for old-growth forests (Linder et al. 1997), should be re-considered.The main question is whether existing forest and hunting laws are sufficient to avoid the observed decline in forest species, or, if new policies and legislation are needed. A conflict-centered approach, identifying the drivers and how to manage them (Nie 2003), e.g., analysis of the distribution of rights, and enhanced stakeholder and local community involvement, should be preferred to an impactbased approach (Niemelä et al. 2005) through mere legislation changes. However, putting aside the aspects of the property rights that have emerged from feudalistic regimes of the past, it now seems clear that hunters should not be the sole group of people legally allowed to regulate the population of deer. A change to a more pluralistic operation is required, with more rights given to landowners. A recent decision of the European Court of Human Rights opens a path for further changes: the judgment states that the exercise of hunting violates the landowner's right to the peaceful enjoyment of his possessions (European Court of Human Rights 2012). However, this judgment only encourages landowners to oppose the exercise of hunting; it does not challenge the position of hunters and the State regarding the intensity of hunting. The situation may become worse, if only hunting restrictions and not the regulation of deer populations is a property right. Obviously, the situation of browsing affecting ecosystem properties of deciduous forest will only change with a modernization of the legal frameworks for hunting. 


\section{Conclusions}

We observed an increasing dominance of Fagus with stand age in both Romania and Germany. Independently from natural succession, there is an enhancing effect of browsing in both regions, but largest in protected areas in Germany. The apparent enhancement of succession by browsing has its cost, namely to distort community dynamics at early stages of stand development. Browsing eliminates a major portion of species at regional scale.

Browsing intensity was six times higher in Germany than in Romania, irrespective of palatability, presumably due to the different levels of ungulate populations. The loss of species in Romania was possibly also associated with illegal grazing. Browsing had a more consistent effects on tree species losses than light. Management had minor effects.

The use of a grid-based inventory is proposed as an alternative method to fencing experiments for the detection of browsing. The boundary line method used here quantifies the maximum possible and achievable tree diversity under all combinations of stand age, canopy opening, and management.

In Germany, all the investigated forest management systems, even the protected nature reserves, suffer from deer browsing. The only possible way of mitigation is a change in deer management. This appears possible only by a change of the legal framework on hunting. The result of our extensive analysis of $>6,500$ plots provides evidence that the loss of tree species in tree regeneration and across succession is likely to have major consequences for other organisms (e.g. macrolepidoptera).

The present hunting practices that support overabundant ungulate populations constitute a major threat to the biodiversity of deciduous forests in Germany and Romania and to other places with similar ungulate management.

\section{Acknowledgements}

We thank Jens Schumacher, Informatics Department of the University of Jena, for support in the statistical analyses, the Deutsche Forschungsgemeinschaft for financial support (Az.: Schu 331/19-2), and the Max Planck Gesellschaft for support of JW. The project was also supported by the EU-project FUNDIV (FunDivEurope-265171) and GHG Europe (GHGEurope-244122). OB and MT were supported by a grant of the Romanian National Authority for Scientific Research, CNCS - UEFISCDI, project number PN-II-ID- 530 PCE-2011-3-0781. We thank John Gash for English editing.

\section{References}

Abs C., Ewald J., Walentowski H., Winter S., 2008. Untersuchungen der Schattentoleranz von Baumarten auf der Grundlage der Datenbank bayerischer Naturwaldreservate [Investigations of the shade tolerance of tree species based on the database of the nature reserves in Bavaria]. Tuexenia 28: 23-40.

Adams S.N., 1975. Sheep and cattle grazing in forests: a review. Journal of Applied Ecology 12: 143-152. DOI: $10.2307 / 2401724$.

Allombert S., Gaston A.J., Martin J.L., 2005. A natural experiment on the impact of overabundant deer on songbird populations. Biological Conservation 126: 1-13. DOI: $10.1016 /$ j.biocon.2005.04.001.

Ammer C., 1996. Impact of ungulates on structure and dynamics of natural regeneration of mixed mountain forests in the Bavarian Alps. Forest Ecology and Management 88: 43-53. DOI: 10.1016/S0378-1127(96)03808-X.

Arbuckle J.L., 2010. IBM SPSS Amos 19 User's Guide. - Amos Development Corporation, Crawfordville, FL, USA.

Begon M., Harper J.L., Townsend C.R., 1990. Ecology: individuals, populations and communities. $2^{\text {nd }}$ eds. Blackwell, $945 \mathrm{p}$.

Brousseau P.M., Hébert C., Cloutier C., Côté S.D., 2013. Short-term effects of reduced white-tailed deer density on insectcommunities in a strongly overbrowsed boreal forest ecosystem. Biodiversity and Conservation 22: 77-92. DOI: 10.1007/s10531-012-0400-5.

Burschel P., Huss J., 2002. Grundriss des Walödbaus [Compendium on silviculture] $3^{\text {rd }}$ edn. Ulmer, $487 \mathrm{p}$.

Caquet B., Montpied P., Dreyer E., Epron D., Collet C., 2009. Response to canopy opening does not act as a filter to Fagus sylvatica and Acer sp. advance regeneration 
in a mixed temperate forest. Annals of Forest Science 67: 20-25.

Carlowitz H.C. von 1713. Sylvicultura oeconomica: Anweisung zur wilden Baum-Zucht [Economics of silviculture: regulations for tree production]. Reprint 2000. Braun Verlag, 414 p.

Côté S.D., Rooney T.P., Tremblay J.P., Dussault C., Waller D.M., 2004. Ecological impacts of deer overabundance. Annual Review of Ecology, Evolution, and Systematics 35: 113-147. DOI: 10.1146/annurev.ecolsys.35.021103.105725.

Crawley M.J., 1988. Herbivores and plan population dynamics. In: A.J. Davy, M.J. Hutchings, A.R. Watkinson (eds.), Plant Population Ecology. Blackwell, pp. 367392.

Crisan V., 1994. Jäger? Schlächter Ceauşescu. Verlag Dieter Holzmann, Mainz, 154 p.

Ellenberg H., 1978. Vegetation Mitteleuropas mit den Alpen in ökologischer Sicht [Vegetation of Central Europe including the Alps with an ecological perspective] $2^{\text {nd }}$. edn. Ulmer, $981 \mathrm{p}$.

European Court of Human Rights, 2012. Case of Herrmann v. Germany. Application 9300/7. JudgementStrasbourg, June 26, 2012. URL: http://hudoc.echr.coe. int/sites/eng/pages/search.aspx?i=001-111690

Gardianul, 27.07.2007.

Gautschi A., 2010. Der Reichsjägermeister [The Foreman of hunting in the „Dritte Reich“], Edition Nimrod bei JANA, $352 \mathrm{p}$.

Gerhardt P., Arnold J.M., Hackländer K., Hochbichler E., 2013. Determinants of deer impact in European forests - a systematic literature analysis. Forest Ecology and Management 310: 173-186. DOI: $10.1016 /$ j.foreco.2013.08.030.

Gill R.M.A., 2006. The influence of large herbivores on tree recruitment and forest dynamics. In: K. Danell, R. Bergström, P Duincan, J. Pastor (eds.), Large herbivore ecology, ecosystems dynamics and conservation.

Gill R.M.A., Beardall V., 2001. The impact of deer on woodlands: the effects of browsing and seed dispersal on vegetation structure and composition. Forestry 74 : 209-218.

Gordon I.J., Hester A.J., Festa Bianchet M., 2004. Review: The management of wild large herbivores to meet economic, conservation and environmental objectives. Journal of Applied Ecology 41: 1021-1031. DOI: $10.1111 / j .0021-8901.2004 .00985 . x$.

Grace J.B., 2006. Structural equation modeling and natural systems, Cambridge University Press. DOI: $10.1017 /$ CBO9780511617799.

Hacker H., 1998. Schmetterlinge und Sträucher. [Butterflies and shrubs]. In Sträucher in Wald und Flur. edn. Bayer. Forstverein, pp. 510-520.

Harper J.L., 1977. Population biology of plants, Academic Press.

Heinze E., Boch S., Fischer M., Hessenmöller D. et al., 2011. Habitat use of large ungulates in northeastern Germany in relation to forest management.
Forest Ecology and Management 261: 288-296. DOI: $10.1016 /$ j.foreco.2010.10.022.

Hellström E., Reunala A., 1995. Forestry conflicts from the 1950s to 1983. Research Report 3. Joensuu, Finland, European Forest Institute.

Hessenmöller D., Nieschulze J., von Lüpke N., Schulze E.D., 2011. Identification of forest management types from ground based and remotely sensed variables and the effect of forest management on forest structure and composition. Forstarchiv 82: 171-183.

Hofman G., Pommer U., Jenssen M., 2008. Wildökologische Lebensraumbewertung für die Bewirtschaftung des widerkäuenden Schalenwildes im nordostdeutschen Tiefland [Habitat evaluation for deer in NE-Germany], Eberswalder Forstliche Schriftenreihe 39: 1-207.

Holt R.D., 1977. Predation, apparent competition and the structure of prey communities. Theoretical Population Biology 12: 197-229. DOI: 10.1016/0040-5809(77)90042-9.

Horn H.S., 1974. The ecology of secondary succession. Annual Review of Ecology and Systematics 5: 25-37 DOI: 10.1146/annurev.es.05.110174.000325.

Horsley S.B., Stout S.L., DeCalstea D.S., 2003. Whitetailed deer impact on the vegetation dynamics of a northern hardwood forest. Ecological Applications 13: 98-118. DOI: 10.1890/1051-0761(2003)013[0098: WTDIOT]2.0.CO;2.

Jorritsma I.T.M., Van Hees A.F.M., Mohren G.M.J. 1999. Forest development in relation to ungulategrazing: a modeling approach. Forest Ecology and Management 120: 23-34. DOI: $10.1016 / \mathrm{S} 0378-1127(98) 00540-4$.

Klötzli F., 1965. Qualität und Quantität der Rehäsung in Wald- und Grünland-Gesellschaften des nördlichen Schweizer Mittellandes [Quality and quantity of grazing by deer in forest and grassland communities oft he northern Swiss colline region]. Thesis ETH Zürich, 187 p.

Korpel S., 1995. Die Urwälder der Westkarpaten [The primary forests of the West Carpathian Mountains]. Gustav Fischer Verlag, Jena, 310 p.

Lang G., 1994. Quartäre Vegetationsgeshichte Europas [Vegetation history of Europe in the Quaternary], Gustav Fischer Verlag, Jena, 462 p.

Lessard J.P., Reynolds W.N., Bunn W.A., Genung M.A., Cregger M.A., Felker-Quinn E., Barrios-Garcia N., Stevenson M.L., Lawton R.M., Brown C.B., Patrick M., Rock J.H., Jenkins M.A., Bailey J.K., Schweitzer J.A., 2012. Equivalence in the strength of deer herbivory an above and below ground communities. Basic and Applied Ecology 13: 59-66. DOI: 10.1016/j.baae.2011.11.001.

Linder P., Elfving B., Zackrisson O., 1997. Stand structure and successional trends in virgin boreal forest reserves in Sweden. Forest Ecology and Management 98: 17-33. DOI: 10.1016/S0378-1127(97)00076-5.

Lozano J., Virgos E., Cabezas-Diáz S., Mangas J.G., 2007. Increase of large game species in Mediterranean 
areas: Is the European wildcat (Felis sylvestris) facing a new threat? Biological Conservation. 138: 321-329. DOI: 10.1016/j.biocon.2007.04.027.

Luyssaert S., Hessenmöller D., von Lüpke N., Kaiser S., Schulze E.D., 2011. Quantifying land-use and disturbance intensity in forestry, based on the self-thinning relationship. Ecological Applications 21: 3272-3284. DOI: $10.1890 / 10-2395.1$.

MADR, 2012. Raport tehnic operativ asupra situației din zootehnie la data de 30 iunie 2012 [Operative technical report on zootechnics - June 30, 2012]. URL : http:// www.madr.ro/pages/page.php?self $=01 \&$ sub $=0108 \&$ var $=010803 \&$ art $=0150101$. Accessed: 10.2014 .

Marin G., Bouriaud O., Dumitru M., Nitu D., 2009. Development of Romania's National Forest Inventory. In: Tomppo et al. (eds.), National forest inventories: pathways for common reporting, Springer, Heidelberg.

Mayer H., 1984. Wälder Europas [The forests of Europe]. G. Fischer Verlag, 691 p.

Milner J.M., Bonenfant C., Mysterud A., Gaillard J.M., Csányi S., Stenseth N.C., 2006. Temporal and spatial development of red deer harvesting in Europe: biological and cultural factors. Journal of Applied Ecology 43: 721-734. DOI: $10.1111 /$ j.1365-2664.2006.01183.x.

Milner J.M., Nilsen E.B., Andreassen H.P., 2007. Demographic side effects of selective hunting in ungulates and carnivores. Conservation Biology 21: 35-47. DOI: 10.1111/j.1523-1739.2006.00591.x.

Ministerul Mediului şi Pădurilor, 2011. Starea pădurilor, 2010. [Forest report, 2010].Web: http://www.mmediu. ro/paduri/management_forestier/2011-11-18_management_forestier_stareapadurilor2010.pdf. Accessed: 10.2014.

Mitchell F.J.G., Kirby K.L., 1990. The impact of large herbivores on the conservation of semi-natural woods in the British uplands. Forestry 63: 333-353. DOI: 10.1093 /forestry/63.4.333.

Modrý M., Hubený D., Rejsek K., 2004. Differential response of naturally regenerated European shade tolerant tree species to soil type and light availability. Forest Ecology and Management. 188: 185-195. DOI: 10.1016/j.foreco.2003.07.029.

Müller J., Bußler H., Brustel H. et al., 2005. Urwald relic species - Saproxylic beetles indicating structural qualities and habitat tradition. Waldökologie online 2: 106113.

National Institute of Statistics, 2013. Efective de animale existente la 1 decembrie 2013. [Existing domestic livestock - December 1, 2013]. Web: http://www.insse.ro/ cms/files/statistici/comunicate/com_anuale/Efec_anim/ efec_anim_df06.pdf. Accessed: 10.2014.

Nationalpark Hainich, 2013. Waldentwicklung im Nationalpark Hainich [Forest dynamics in the national park Hainich]. Erforschen Bd. 3: 1-166.

Nie M., 2003. Drivers of natural resource-based political conflict. Policy Sciences 36: 307-341. DOI: 10.1023/B:OLIC.0000017484.35981.b6.
Niemelä J., Young J., Alard D., Askasibar M. et al., 2005. Identifying, managing and monitoring conflicts between forest biodiversity conservation and other human interests in Europe. Forest Policy and Economics 7: 877-890. DOI: 10.1016/j.forpol.2004.04.005.

Pépin D., Renaud P.C., Boscardin Y., Goulard M., Mallet C., Anglard F., Ballon P., 2006. Relative impact of browsing by red deer on mixed coniferous and broad-leaved seedlings - An enclosure-based experiment. Forest Ecology and Management 222: 302-313. DOI: $10.1016 /$ j.foreco.2005.10.034.

Petrițan A.M., von Lüpke B., Petritan I.C., 2009. Influence of light availability on growth, leaf morphology and plant architecture of beech (Fagus sylvatica L.), maple (Acer pseudoplatanus L.) and ash (Fraxinus excelsior L.) saplings. European Journal of Forest Research. 128: 61-74. DOI: $10.1007 / \mathrm{s} 10342-008-0239-1$.

Petrițan I.C., Marzano R., Petrițan A.M., Lingua E., 2014. Overstorey succsession in a mixed Quercus petraeaFagus sylvatica old growth forest revealed through the spatial pattern of competition and mortality. Forest Ecology and Management 326: 9-17.

R Development Core Team 2010. R: a language and environment for statistical computing. Vienna, Austria. R Foundation for Statistical Computing.

Reimoser F., Gossow H., 1996. Impact of ungulates on forest vegetation and its dependence on the silvicultural system. Forest Ecology and Management 88: 107-119. DOI: 10.1016/S0378-1127(96)03816-9.

Scherber C., Eisenhauer N., Weisser W. W. et al., 2010. Bottom-up effects of plant diversity on multitrophic interactions in a biodiversity experiment. Nature 468: 553-556. DOI: 10.1038/nature09492.

Schoonmaker P., McKee A., 1988. Species composition and ddiversity during secondary succession of coniferous forests in the Western Cascade Mountains of Oregon. Forest Science 34: 960-979.

Schulze E.D., 2014. Zuwachs und Entmischung der Verjüngung im Laubwald mit und ohne Wildverbiss [Growth and succession of regeneration in deciduous forests with and without fencing] AFZ-Der Wald 11/2014, 26-27.

Schulze E.D., Bazzaz F.A., Nadelhoffer K.J., Koike T., Takatsuki S., 1996. Biodiversity and ecosystem functioning of temperate deciduous broad-leaved forests. SCOPE 55: 71-98.

Schulze E.D., Hessenmöller D., Seele C., Wäldchen J., von Lüpke N., 2010. Die Buche: eine Kultur- und Wirtschaftsgeschichte [The Beech: a cultural and economic history]. Biologie in unserer Zeit 3/2010, 171-183. DOI: $10.1002 /$ biuz.201010421.

Skarpe C., Hester A., 2008. Plant traits, browsing and grazing herbivores, and vegetation dynamics. In: I.J. Gordon \& H.H.T. Prins (eds.), The ecology of browsing and grazing. Ecological studies 195: 217-261.

Striepen K., 2000. Einfluß von Wildverbiss auf die Verjüngungsentwicklung von Buchen- und Buchenmischwäldern in Nordrhein-Westfalen [Influence of browsing on 
regeneration of beech and mixed beech forests in NWGermany]. NUA-Seminarberichte 4: 91-107.

Tanentzap A.J., Bazley D.R., Koh S., Timciska M., Haggith E.G., Carleton and T.J., Coomes D.A., 2011. Seeing the forest for the deer: Do reductions in deer-disturbance lead toforestrecovery? Biological Conservation 144:376-382. DOI: $10.1016 /$ j.biocon.2010.09.015.

Thoms C., Gattinger A., Jacob M., Thomas F.M., Gleixner G., 2010. Direct and indirect effects of tree diversity drive soil microbial diversity in temperate deciduous forest. Soil Biology \& Biochemistry 42: 1558-1565. DOI: 10.1016/j.soilbio.2010.05.030.

Thüringen Forst 2010 Verbiss- und Schälsituation im Freistaat Thüringen [Browsing and bark-peeling in Thuringia]. Internal information.

Tottewitz F., Stubbe C., Ahrens M., Dobias K., Goretzki J., Paustian K.H., 1996. Die Losungszählung als Methode der Bestandsschätzung von wiederkäuenden Schalenwildarten [Dropping-counts as a method for estimating deer populations]. Zeitschrift für Jagdwissenschaft 42: 111-122.

Tremblay J.P., Hout J., Potvin F., 2007. Density-related effects of deer browsing on the regeneration dynamics of boreal forests. Journal of Applied Ecology 44: 552-562. DOI: $10.1111 /$ j.1365-2664.2007.01290.x.

Van Hees A.F.M., Kuiters A.T., Slim P.A., 1996. Growth and development of silver birch, pedunculate oak and beech as affected by deer browsing. Forest Ecology and Management, 88: 55-63. DOI: $10.1016 / \mathrm{S} 0378-1127(96) 03809-1$.

von Lüpke B., 2005. Canopy management, plant quality and harvesting regime. In: G. Oleskog, M. Löf, (eds), The ecological and silvicultural bases for underplanting beech (Fagus sylvatica L.) below Norway spruce shelterwood (Picea abies L. Karst). Frankfurt am Main, Schriften aus des Forstlichen Fakultät der Universität Göttingen, Band 139. J.D. Sauerländer's Verlag.

Walentowski H., Bussler H., Bergmeier E., Blaschke M. et al., 2010. Sind die deutschen Buchenwälder adäquat für die Erhaltung der buchenwaldtypischen Flora und Fauna? Eine kritische Bewertung basierend auf der Herkunft der Waldarten des mitteleuropäischen Tief- und Hügellandes [Are the German beech-forests sufficient for protection of the characteristic flora and fauna of beech forests? A critical evaluation based on the origin of species in the Collin forests of Germany]. Forstarchiv 81: 195-217.
Wittmann F., Schöngart J., Montero J.C., Motzer T., Junk W.J., Piedade M.T.F., Queiroz H.L., Worbes M., 2006. Three species composition and diversity gradients in white-water forests across the Amazon basin. Journal of Biogeography 33: 1334-1347. DOI: $10.1111 /$ j.1365-2699.2006.01495.x.

\section{Supporting Information}

The online version of the article includes the Supporting Information

\section{Supp. Tables}

Supp.-Table 1: Summary of stand inventory parameters of the investigated forest management types

Supp.-Table 2: Relation between species loss and browsing or stand characteristics

Supp.-Table 3: Results of structural equation models

Supp.-Table 4: Browsing intensity

\section{Supp. Figures}

Supp.-Fig. S1: Total number of tree taxonomic units (species and genera)

Supp.-Fig. S2: The relation between tree age and $\mathrm{DBH}$

Supp.-Fig. S3: Tree density in the regeneration layer

Supp.-Fig. S4: Single Correlations (not including interactions) of the structural equation model

Supp.-Fig. S5: Scatter diagram of tree species number per inventory plot $\left(500 \mathrm{~m}^{2}\right)$

Supp.-Fig. S5: Browsing in $\mathrm{HC} 1$ expressed as percentage of affected individuals 